DOI: $\square$ https://doi.org/10.15407/techned2020.06.025

\title{
FEATURES OF SECTIONING THE TURNS OF THE TRANSFORMING ELEMENT OF THE TRANSFORMER-KEY ACTUATING STRUCTURE IN THE BOOST CHANNEL OF THE DC POWER SYSTEM
}

Journal

Publisher

ISSN

Issue

Pages
Tekhnichna elektrodynamika

Institute of Electrodynamics National Academy of Science of Ukraine 1607-7970 (print), 2218-1903 (online)

No 6, 2020 (November/December)

$25-31$

\section{Authors}

\section{K.O. Lypkivskyi*, A.G. Mozharovskyi**}

Institute of Electrodynamics of National Academy of Sciences of Ukraine,

pr. Peremohy, 56, Kyiv, 03057, Ukraine,

e-mail: lypkivskyk@ukr.net; AnatMozhrvsk@ukr.net

* ORCID ID : https://orcid.org/0000-0002-3292-1360

** ORCID ID : https://orcid.org/0000-0001-9801-2728

\section{Abstract}

One of the effective ways to ensure the normalized operation of the electricity consumer with an unstable primary power source is the organization of the corresponding voltage supply channel. In a system with a direct current source, the voltage supply is implemented by introducing a rectifier semiconductor bridge in series with the load, into the diagonal of which AC energy is supplied, the voltage level of which is purposefully changed by a corresponding converter with a transformer- and-switches executive structure (TSES). To achieve high efficiency of the use of key elements of TSVS, it is proposed to assign the functions of rectification and voltage regulation to a specific class of TSES - a multilevel rectifier consisting of a transformer and a finite set of parallel connected pairs of serially connected thyristors, the common points of which are connected to the corresponding taps of the sectioned secondary turns of the transformer. By discrete-time control of thyristors, it is necessary to regulate voltage levels, it is attached. The linearity of the scale of these levels is ensured by the proposed transformer sectioning law. This power supply system is characterized by small energy losses in semiconductor elements (only two thyristors work at a time), and the a priori impossibility of emergency situations during transitions from one level to another. References 14, figures 3, tables 3. 
Key words: transformer-and-switches executive structure, DC power systems, booster channel, multi-level rectifier, winding sectioning law.

Received: 08.07.2020

Published: 21.10.2020

\section{References}

1 Kyrylenko O.V., Pavlovsky V.V., Lukanenko L.M., Trach I.V. Problems of integration of renewable energy sources into weak electric grids. Tekhnichna Electrodynamika. 2012. No 5. Pp. 25-26. (Ukr)

2. Statistics Time Series. URL: https://www.irena.org/Statistics/View-Data-by-Topic/Capacityand-Generation/Statistics-Time-Series (Accessed at 03.07.2020).

3. Mohammad Sarvi, Haniyeh Marefatjou. Compensation of Voltage Single-Phase SAG and SWELL Using Dynamic Voltage Restorer and Difference Per-Unit Value Method. International Journal of Electrical and Computer Engineering

(IJECE). 2013. Vol. 3. No 1. Pp. 83-92.

DOI:

https://doi.org/10.11591/ijece.v3i1.2134

4. Santilio F.P., Silva T.V., Oliveira J.C., Barbosa J.A.F. A computational and experimental performance analysis of an electromagnetic voltage regulator proposal throughout controlled series voltage injection. Renewable Energies and Power Quality Journal (RE\&PQJ). 2012. Vol. 1. No 10. Pp. 767-772. DOI:

https://doi.org/10.24084/repqj10.465

5. Young Choon Chung, Alternating current power control device. Patent US No 5808454, 1998.

6. Lypkivskyi K.O., Khalikov V.A., Mozharovskyi A.G. Device for regulating the magnitude of AC voltage. Patent UA No 67805, 2012. (Ukr)

7. Timothy F. Glennon,Byron R. Mehl. Regulated AC/DC converter. Patent US No4739466, 1988.

8. Allan David Crane, Warren Mark Blewi. Power converters. Patent US No 9800161B2, 2017.

9. Lypkivskyi K.O. Transformer-and-Switches Executive Structures of Alternating Current Voltage Converters. Kiev: Naukova Dumka, 1983. 216 p. (Rus).

10. Willems W., Vandoorn T.L., De Kooning, J. D., Vandevelde L., Development of a smart transformer to control the power exchange of a microgrid. 4th International Conf. Innovative Smart Grid Technologies Conference Europe 
(ISGT - Europe 2013). At Lyngby, Denmark. 6-9 Oct. 2013. Pp. 1-5. DOI: http://dx.doi.org/ 10.1109/ISGTEurope.2013.6695300

11. Bimal K Bose. Power Electronics - Why the Field is so Exciting. IEEE Power Electronics Society Newsletter Fourth Quarter 2007. Vol. 19. No 4. Pp. 11-20.

12. Lypkivskyi K.O. Executive body of discrete AC voltage stabilizer with decomposition of key switch elements. Tekhnichna Elektrodynamika. 2006. No 2. Pp. 35-41. (Rus)

13. Lypkivskyi K.O., Mozharovskyi A.G. Organization of a boost channel in the structure of a renewable DC energy source. Tekhnichna Elektrodynamika. 2020. No 5. Pp. 31-34. (Ukr) DOI: https://doi.org/10.15407/techned2020.05.031

14. Lypkovskyi K.A., Ozerianskyi A.A., Gradoblianskyi V.M. Features of the construction of transformer-thyristor regulators of rectified voltage. Methods and means of converting electrical energy parameters. Kiev: Naukova Dumka, 1977. Pp. 24-28. (Rus)

$\underline{\text { PDF }}$

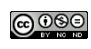

This work is licensed under a Creative Commons Attribution-NonCommercial-NoDerivatives 4.0 International License 